\title{
加熱鋳型式連続鋳造法により製造された ステライト材の性質と応用
}

\author{
山崎裕之计 大野篤美* 清 水 亨** \\ *千葉工業大学工学部金属工学科

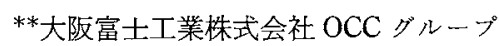

J. Japan Inst. Metals, Vol. 58, No. 9 (1994), pp. 1061-1066

\begin{abstract}
Mechanical and Physical Properties of Stellite Rods Produced by Heated-Mold Continuous Casting Method (OCC)

Hiroyuki Yamazaki*, Atsumi Ohno* and Toru Shimizu**

*Department of Metallurgical Engineering, Chiba Institute of Technology, Narashino

**O.C.C. Division, OSAKA FUJI Corporation, Amagasaki
\end{abstract}

Stellite alloy rods produced by the heated mold continuous casting (Ohno Continuous Casting) method exhibit a unidirectional structure. The mechanical and physical properties of these products have been examined. It was found that the OCC stellite materials have superior wear, corrosion and shock resistance properties compared with those of weld-deposited stellite materials. Thus, it was proposed in this work that OCC rods with different crosssectional shapes can be simply welded onto the objects which require wear resistance by using the existing joining techniques.

(Received March 10, 1994)

Keywords: Ohno continuous casting process, stellite, net or near net shape casting, rod with different cross-sections

\section{I. 緒言}

一般にステライトと呼ばれている Co-Cr-W 系合金は，熱 間，冷間を問わず硬く，優れた耐摩耗性，耐食性を有する材料 として知られ，耐摩耗性が要求される製品の表面硬化肉盛溶接 用の材料として，各種工業分野で広く用いられている。ステラ イトを用いた肉盛溶接は, Fig. 1(a)に示したように一般に TIG 溶接もしくは酸素ーアセチレンガ大を用いたガス豁接など に上り何層か以肉盛を行い, その後, 切削または研削加工に上 り使用形状火成形して製品としている。しかしながら，ステラ イトの肉盛溶接は, める程度熟練が必要であるとともに, 極め て硬いために溶接後の加工に非常に手間が掛かる。そこで肉盛 部の形状をもったステライトの棒材をFig. 1(b)に示したよう に，直接母材に接合することにより，溶接による諸問題を解決 し，さらに肉盛溶接後の加工工程も著しく簡略化でさるものと 考えられる。著者らは，すでにこの方法に用いるための肉盛部 の形状を有したステライト棒材が，加熱鋳型式連続鋳造法 (OCCプロセス(1))に上り連続的に得られること, さらに得ら れた鋳塊は，等軸晶などの無い一方向凝固組織からなり，な就 かつ巣や気泡などの鋳造欠陷の存在しない健全な鋳塊であるこ

$\uparrow$ 千葉工業大学大学院生



(a)
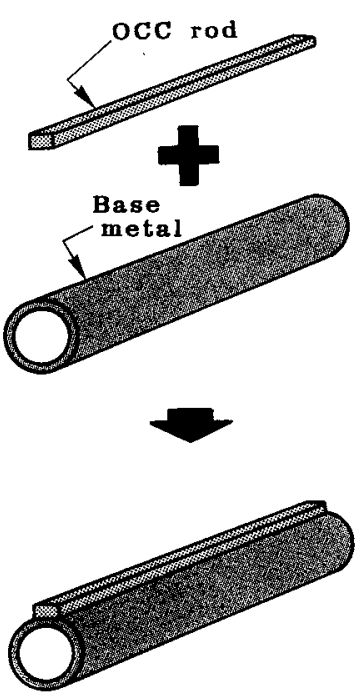

(b)
Fig. 1 Comparison of the conventional method (a) with the proposed method (b). 
とを報告(2)した．

本研究は，OCCプロセスにより得られたステライト鋳塊を 有效に使用寸るために，去の性質を明らかにすることを目的と し，さらにその㐫用としてOCCステライト鋳塊を母材火接合 するお法についてて検討した。

\section{II. 実 験 方 法}

\section{1. 試験片の作製}

Table 1 は, 本研究に用いたステライトNo. 6 と他の代表的 なステライトの組成特よび物性的性質を示したすのである。 テライトNo.6は，ステライトの中では比較的硬さが低く，各 試験片の切り出し作業が容易に行光る利点が莗る。

試験片は，ステライトNo. 6 の OCC 鋳塊から切り出したも のと, その比較材として, 厚さ $20 \mathrm{~mm} の \mathrm{SUS} 316 \mathrm{~L}$ スンレ ス鋼にステライトNo.6を肉盛溶接し，その部分を切り出した すのを用いた(以下本論文では，これを肉盛金属と呼ぶ)。な お，溶接時には，健全な肉盛層を得るために，Arガスを用い たTIG 溶接を施し，その溶接条件は，予熱 $300^{\circ} \mathrm{C}$, 溶接電流 $180 \mathrm{~A}$ (直流正極性)で, 直径 $6.4 \mathrm{~mm}$ の溶接棒で，手盛で 5 6 層の多層盛りした．各試験片の切り出しは，極薄砥石を用 い，必要に応じて超硬合金製(JIS K10)の切削工具に上る加工 扣よび研磨布紙により表面仕上げを行った。

\section{2. 腐食試験}

ステライトは，優れた耐食性を有する材料として知られてい る.そこで，OCC 鋳塊と従来法の肉盛溶接した肉盛金属部分 との耐食性について比較を行った。

哜験片の形状は， $12 \times 14 \times 4 \mathrm{~mm}$ であり，表面は JIS 400 番 の研摩布紙で仕上げた後に，メタノールで洗浄し乾燥させた。

そして, 試験片全体を， $35 \%$ 塩酸水溶液に，室温(平均 $25^{\circ} \mathrm{C}$ ) で $72 \mathrm{~h}$ 浸漬させて，浸漬前後の重量賕化の測定および腐食後 の試験片の外観を観察した。

比較材は，母材の希釈による影響が大きく，鉄とニッケルの 堌量が認められた每材との境界面から 1 5 mm 層の(a) と, 任とんど成分変化が見られなかった 6 10 $\mathrm{mm}$ 層の(b)の 2 種 類の肉盛金属を用いた。 Table 2 亿, 試駼に用いた各試験片の 成分分析值を示した。

\section{3. 摩耗試験}

ステライトは，硬く優れた耐摩耗性を有した材料として知ら れ，特に金属間摩耗櫌れた特性を示寸と言われている。そこ で，耐摩耗性を比較した。

Table 1 Chemical composition and physical properties of stellite alloys.

\begin{tabular}{|c|c|c|c|c|c|c|c|c|}
\hline & \multicolumn{5}{|c|}{$\begin{array}{c}\text { Chemical composition } \\
\text { (mass } \%)\end{array}$} & \multirow{2}{*}{$\begin{array}{l}\text { Melting } \\
\text { temperature } \\
\left({ }^{\circ} \mathrm{C}\right)\end{array}$} & \multirow{2}{*}{$\left|\begin{array}{l}\text { Density } \\
\left(\mathrm{kg} / \mathrm{m}^{3}\right)\end{array}\right|$} & \multirow{2}{*}{$\begin{array}{c}\text { Specific } \\
\text { heat } \\
J /(\mathrm{kg} \cdot \mathrm{K})\end{array}$} \\
\hline & Co & $\mathrm{Cr}$ & $\mathrm{W}$ & $\mathrm{C}$ & $\mathrm{Fe}$ & & & \\
\hline Stellite No. 1 & Bai. & 30 & 12 & 2.5 & $<3$ & 1265 & 8480 & 393.3 \\
\hline Stellite No. 6 & Bal. & 28 & 4 & 1.0 & $<3$ & 1290 & 8420 & 422.6 \\
\hline Stellite No. 12 & Bal. & 29 & 8 & 1.35 & $<3$ & 1285 & 8470 & 410.0 \\
\hline
\end{tabular}

Table 2 Chemical composition of specimens used for corrosion testing.

\begin{tabular}{l||c|c|c|c|c|c}
\hline \hline & $\mathrm{Co}_{0}$ & $\mathrm{Cr}$ & $\mathrm{W}$ & $\mathrm{C}$ & $\mathrm{Fe}$ & $\mathrm{Ni}$ \\
\hline Welding rod & 64.03 & 28.78 & 5.00 & 1.26 & 0.37 & 0.13 \\
\hline Deposited metal (a) & 60.41 & 28.15 & 4.55 & 1.09 & 4.48 & 1.89 \\
\hline Deposited metal (b) & 64.10 & 28.66 & 4.85 & 1.18 & 0.62 & 0.18 \\
\hline OCC rod & 65.36 & 28.18 & 4.90 & 1.04 & 0.27 & 0.12 \\
\hline
\end{tabular}

Deposited metal (a) was taken near the base metal and (b) near the surface.

試験には, ピソーディスク式摩耗試験機のピン先に, 板状の 試験片が固定でさるように改良したものを用いた．先ずピンの 先火，厚さ $6 \mathrm{~mm}, 10 \mathrm{~mm}$ 角の試駼片を取り付け，相手材の円 盤の中心から $75 \mathrm{~mm}$ の位置に, 試験片の中心がくるように固 定した。

この時, 相手材には, 厚さ $15 \mathrm{~mm}$, 直径 $200 \mathrm{~mm} の \mathrm{~S} 45 \mathrm{C}$ の調質材 (平均硬さ: HRB97)を用いた。な拉試験片の表面は, 研摩布紙伛より表面粗さを $R a 0.2 \mu \mathrm{m}$ とし,さらに相手材の 表面粗さを Ra $1.2 \pm 0.1 \mu \mathrm{m}$ に表面を仕上げた。

これらを用いて, 試験片に $294 \mathrm{~N}$ の荷重を掛けながら, 相 手材を一方向に回転させ, 摺動速度 $1.75 \mathrm{~m} \cdot \mathrm{s}^{-1} て ゙ 1800 \mathrm{~s}$ 試験 乙, 試験前後の試験片の重量変化特よび表面粗さを測定した。 な狺，肉盛金属は，母材の希釈による成分変化が注と几ど認め られなかった母材との境界面から約 $8 \mathrm{~mm}$ 離れた箇所を摺動 させ，これに対して，OCC 鋳塊はその長さ方向と垂直方向の 2 方向で相手材を摺動させた。

Fig. 2 K，各試験片の摺動面のミクロ組織の写真を示した. 写真の白色の樹枝状組織が, タングステン, クロムを含むコバ ルト固溶体であり，その間は，同固溶体とクロム，タングステ ン複炭化物の共晶組織である. 特に硬い複炭化物の状熊が耐摩 耗性に影響を与兄るるのと考えられる。李た，ステライトは金 属間摩耗優れた材料で㐫ため，潤滑油を用いて摺動させる とほとんど摩耗しなくなり，その結果から比較を行らことが困 難であることから，本試験では無潤滑で㥜動させた。

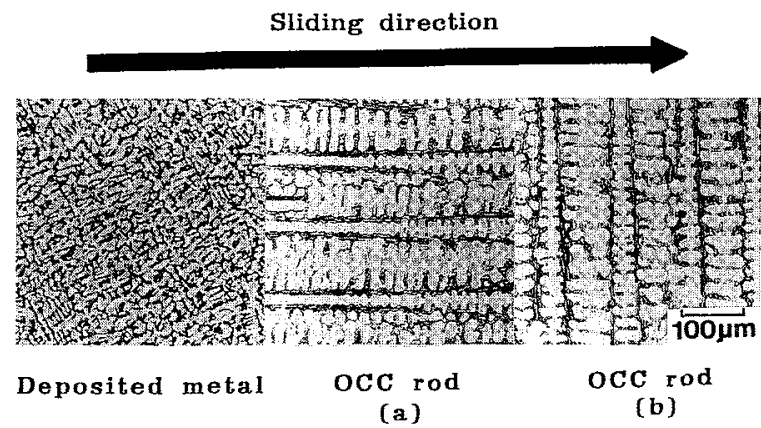

Fig. 2 Microstructures of the specimens and sliding direction during wear testing. (a) Sliding direction is parallel to casting direction of the rod and (b) perpendicular to casting direction (tested on transverse cross-sectional plane of the cast rod). 


\section{4. 衝撃試験}

ステライトは，炭素を多く含有するために極めて硬い材料で あるが，そのぶん僅性に劣る。そこで，耐衝撃性を比較した。 試験には，294.2J 形のッャルピー衝撃試験機を用いた。

また一般には，試験片の中心に V 型もしくはU 型の切欠き 部を設け，その裹側から衝撃を加えて試験を行っている。しか しながら本試料は, 硬くその加工が困難であり,さらに脆性破 壊が予想されたことから，切欠さ部を設けると比較材との衝擊 值の差が顕著にでないもの上判断し，切欠き加工は行わずに， 室温(約 $27.5^{\circ} \mathrm{C}$ ) で試験片の中心飞正確に衝撃を与えた。

なお，試験片に衝撃を与えた方向は，肉盛金属では，実際の 使用状況を考兄，母材方向から成長した組織之同一方向に衝撃 を与允た。これに対して OCC 鏻塊は，これを母材に接合して 用いた場合，鋳塊の長さ方向《対して垂直方向に衝摮が加わる あのと考光，その方向に衝撃を与克た。

\section{III. 実験結果および考察}

\section{1. 耐食性に及ぼす疑固組織の影響}

$35 \%$ 塩酸水溶液に, 室温 (平均 $25^{\circ} \mathrm{C}$ ) で $72 \mathrm{~h}$ 浸漬させた試験 片の腐食減量を Fig. 3 に示した。このよらに, OCC 鋳塊は肉 盛金属に比べて著しい耐食性の向上が認められた，崔食後の試 験片を観察すると，Fig. 4 の OCC 鋳塊は，均一に全面腐食し ているのに対し, 肉盛金属は, 部分的に腐食が進行している籄 所が見られた。

ステライトNo. 6 は，約 28 mass\%のクロムを含有すること から，このクロムが表面に薄く徴密な保護膜を形成するため に，耐食性が優れているものと考元られる，肉盛金属に乱い て, 部分的な腐食の進行が見られた理由は，このクロムが均一 に含有されず，ビードや結晶粒界などでク口ムの偏析が起こ り，その周辺でクロムの希薄層が存在したためと考光られる。 さらに,プローホールなどの内部欠陥が存在した場合は, 特に

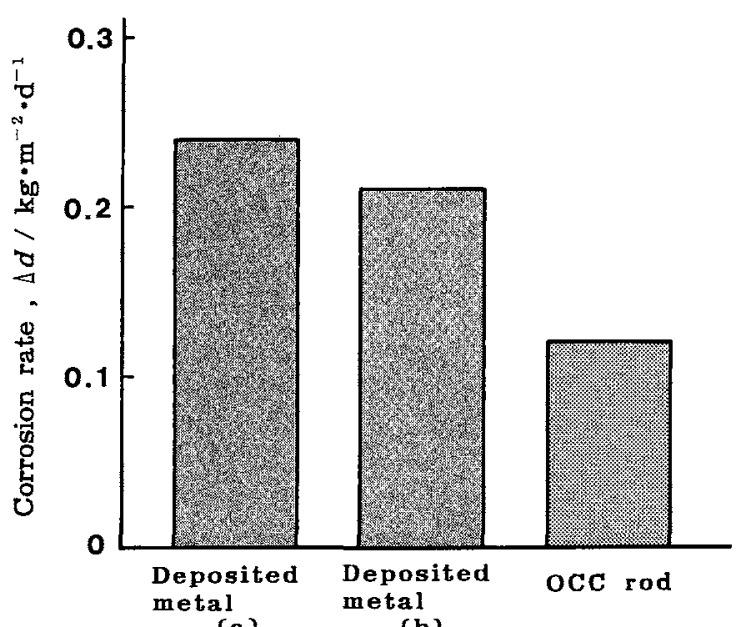

(b)

Fig. 3 Results of corrosion test in which samples were immersed in a $35 \%$ hydrochloric acid solution at $25^{\circ} \mathrm{C}$ for 72 h. Deposited metal (a) was taken near the base metal and (b) near the surface.

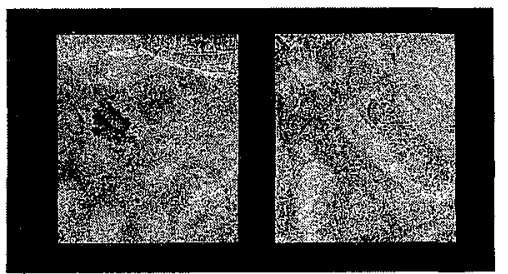

(a)

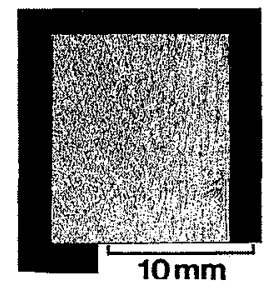

OCC rod
Fig. 4 Surface appearance of the specimens after corrosion testing. Deposited metal specimen (a) was taken near the base metal and (b) near the surface.

その部分に扎いて腐食が進行すると考えられる。また，母材に 近い1 $5 \mathrm{~mm}$ 層の肉盛金属(a)では，母材の希积に上る鉄の 増量が認められたことから，その影響を受けたものと考えられ， 6〜10 mm 層の (b) 上り耐食性の劣化が認められた。

これに対し OCC 鋳塊は, 均一な一方向凝固組織を示してい たことから溶質の偏析が少なく，さらに巣や気泡などの腐食が 進行するような䇢所が存在しなかったために，全面腐食上なり 耐食性が優れていたと考えられる。

\section{2. 耐摩耗性に及ぼす疑固組織の影響}

一般に耐摩耗性は，組織が細かく硬く強度の高い材料で势る ほど優れた值を示すと言われている。本試験に用いたOCC 鋳 塊は, Fig. 2 に示したように, 肉盛金属に比べ組織が大きく, 平均硬さは肉盛金属が $H_{v} 487$ 亿対し， $H_{v} 453$ と低い值でめっ た。このことから考兄ると，耐摩耗性はOCC 鋳塊が肉盛金属 より劣ることが推測される。

しかしながら, 荷重 $294 \mathrm{~N}$, 摺動速度 $1.75 \mathrm{~m} \cdot \mathrm{s}^{-1}$ で 1800 s，無潤滑で S45C 上摺動させた結果，Fig. 5 亿示したように, 鋳塊の長さ方向に相手材を摺動させた OCC 鋳塊(a)は，肉盛

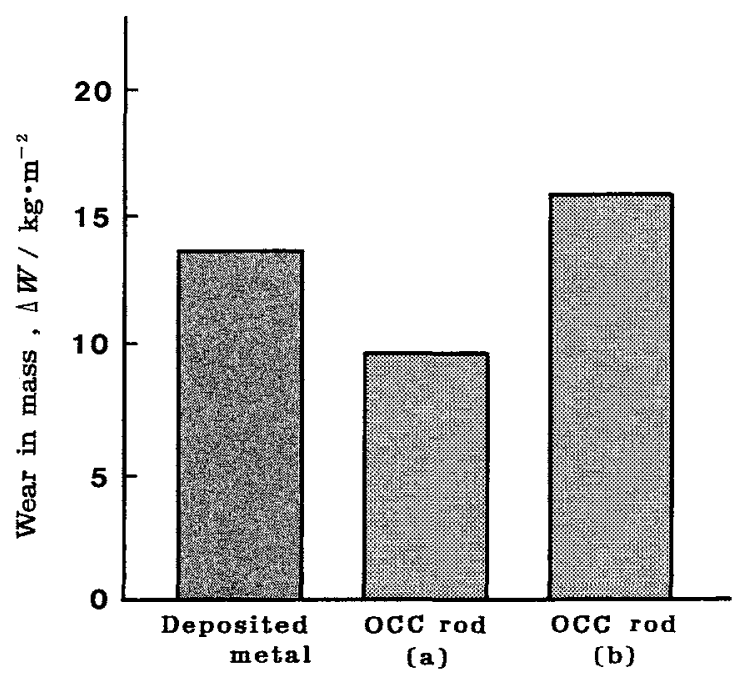

Fig. 5 Results of wear test (without lubricant). (a) Sliding direction is parallel to casting direction of the rod and (b) perpendicular to the casting direction (tested on the transverse cross-sectional plane). Rotating disk material: S45C, Load: $294 \mathrm{~N}$ Speed: $1.75 \mathrm{~m} \cdot \mathrm{s}^{-1}$, Time: $1800 \mathrm{~s}$. 
金属に比べ耐摩耗性の向上が認められた。これは OCC 鋳塊 (a)の組織が，摺動方向に平行に一方向にならんでいたことが 影響したと考㐫られる。そこで摺動後の試験片の表面粗さを摺 動方向に対して横切る万向に測定すると，OCC 鋳塊(a)は $R a$ $2.2 \mu \mathrm{m}, R \max 18.5 \mu \mathrm{m}$ であり, 肉盛金属の $R a 1.6 \mu \mathrm{m}, R \max$ $16.2 \mu \mathrm{m}$ に比べて表面が粗くなっていることがわかった。この ことから OCC 鋳塊(a)の場合，軟らかいマトッックス層での 摩耗が先行し, この時凝着摩耗などにより摩耗粉が発生したと してる，複炭化物相が摺動方向に連続していたため，この摩耗 粉による複炭化物の摩耗が起こりにくく，ある程度マトリック 不層での摩耗が進行すると, 去の後は硬い複炭化物に上り摩耗 が㧕充られるすのと考允られる。なお，この場合の相手材の表 面粗さは，OCC 埥(a)の時が $R a 2.8 \mu \mathrm{m}$ であり，肉盛金属 ではR $R 3.3 \mu \mathrm{m}$ となり, 試験片の表面とは逆に, OCC 鋳塊 (a)を用いた摺動の方が面の荒れが少なかった。

しかしながら，同じ OCC 鋳塊であっても，鋳塊の長さ力向 に垂直方向で相手材を摺動させた OCC 鋳塊(b)の場合には， 肉盛金属と比較して耐摩耗性が劣化した。これは, OCC 鋳塊 (b)では複炭化物相が周期的に存在していたことから，軟らか いマトリックス層で発生した摩耗粉に上り, 硬い複炭化物まで る摩耗され，その後の摩耗が進行したためと考えられる。この ような摩耗形態は，肉盛金属に肪いても生じていたと思われる が，組織が微細であったことから，その影響が少なかったと考 えられる。OCC 鋳塊(b)の摺動後の試験片の表面粗さを測定し た結果，肉盛金属より荒いR $R 2.3 \mu \mathrm{m}, R \max 26.9 \mu \mathrm{m}$ であり， また相手材は肉盛金属と同等の $R a 3.2 \mu \mathrm{m}$ であり,このこと からも組織の粗さが影響したことを示唆している。

\section{3、耐衝撃性と疑固組織の関係}

Fig. 6 はン・シャルピー衝撃試験による衝撃值を示したるの であるＯOCC 録塊は肉盛金属に比べ83\%も衝撃值が高くなる ことが認められた，ステライトNo. 6 は，ステライト合金の中 では比較的鞄性に富んでいるとされているが，炭素を約 1 mass\%も含有するため一般に衝撃値は低く，Fig.7亿示した 試験後の破面の観察から，全体的に脆性破壊が起こっていたこ

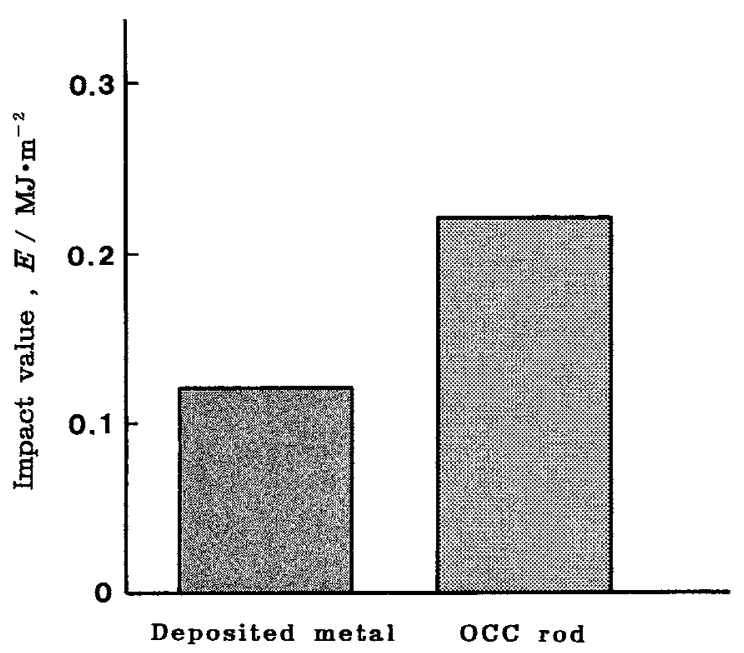

Fig. 6 Results of the Charpy impact test (without notch).

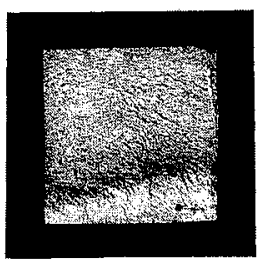

Deposited metal

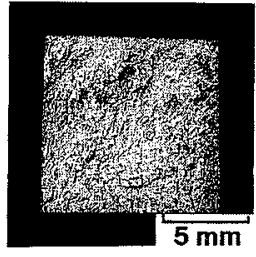

occ rod
Fig. 7 Fractured surfaces after the Charpy test.

とが明らかである。このような脆性破壊の場合，亀裂が生じる とそれが高速で進展してほとんど塑性変形を生しることなく破 断する、そのため, 衝撃エネルギーの吸収のほとんどが，初期 の亀裂発生時行われるものと考学られる.

一方，肉盛金属の破面観察からは，組織に沿った破断が認め られた。これは，肉盛溶接した試験片に衝撃が加わる力向が， 母材から成長した組織と同一方向であったために，衝撃初期に 容易に組織に沿った重裂が発生し，その結果衝撃エネルギーの 吸収が少なかったと考克られる。また，肉盛金属に特いては， その破面にブローホールが存在する試料る見られ，このような 久陷が存在した場合，その箇所が龟裂の起源となり，さらに初 期の衝揧エネルギーの吸収を著しく低下させたと思われる。

本研究で用いた OCC 鉡塊の試験片は，肉盛金属のそれ比 べて軟らかく，このことが衝撃值に影響を与えたことが考えら れる。また，OCC 鉡塊を母材に接合した場合は，衝撃は䤻塊 の長さ方向に一方向に成長した組織付して垂直に加わること から，肉盛金属の試験片で見られた組織に沿った破断は起こら ず，衝撃初期に和ける亀裂の発生が起こりにくい，その結果衝 撃エネルギーの吸収が多くなったと考兄られ，このことが衝撃 値を高くした理由と思われる。さらに OCC 鋳塊には，重裂の 起源となる久陷が存在しなかったことも，衝撃初期の重裂の発 生を抑制したと考えられる。

\section{OCC 鋳塊の溶接への応用}

OCC ステライト鋳塊を母材に対して適切な方法で接合すれ ば，従来から行われていたステライトの肉盛溶接より優れた性 質を示すことが明らかとなった。そこで，実際に OCC 鋳媲を 母材に接合する方法を検討した。

(1) 溶接による接合

溶接を用いる場合は，現在，肉盛溶接に使用している TIG 溶接機やガス溶接機をそのまま利用することができることか ら，その転換が容易であると考えられる．また，母材に棒材を 接合する場合，接合部のみに溶接を施すことから，従来の肉盛 溶接に比べて溶接に要する熱エネルギーを小さくすることが可 能であり，母材温度の上昇を抑觉ることがでさるとともに，溶 接温度の管理が比較的容易となる。ささらに溶接熱による製品の 歪みを少なくすることが可能と考㝋られる. Fig. 8 特よび9 は，溶接により作製したサーマルカッターとスキッドレールの 写真である。これらは実用化されているものである。

Fig. 8 に示したサーマルカッターは，化学紻維などの熱切断 に用いられるもので，管状の母材内にはシース型ヒーターが内 


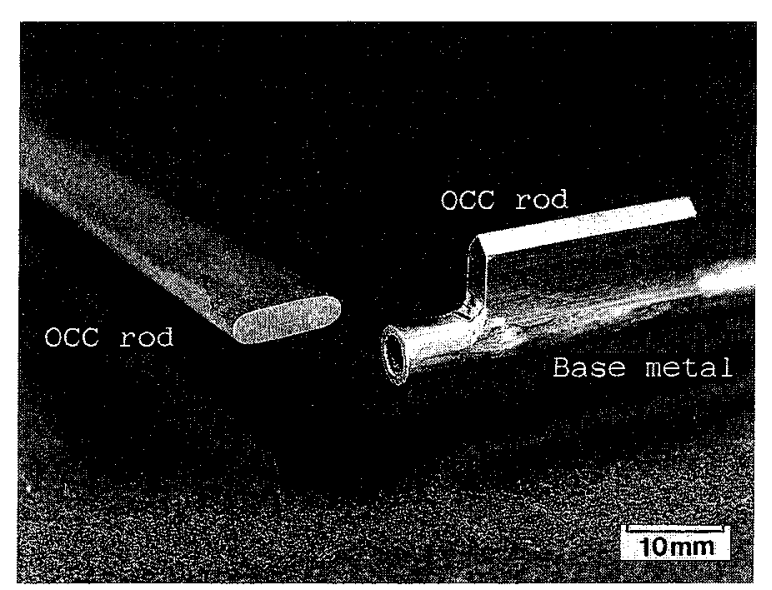

Fig. 8 Cast strip by the OCC process and its application as a thermal blade (joined by TIG welding).

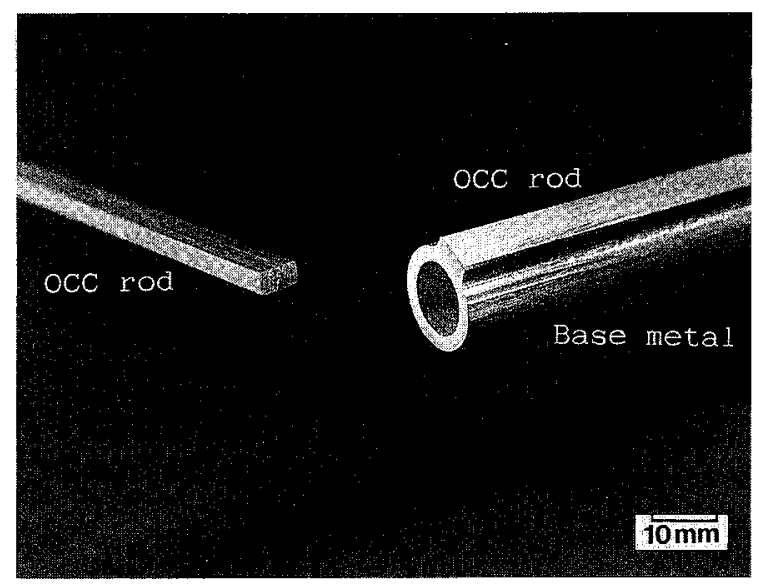

Fig. 9 Rectangular rod produced by the OCC process and its application as a skid rail (joined by TIG welding).

蔵され，刃先を䄪 $600^{\circ} \mathrm{C}$ に加熱して使用する．写真の製品は， SUS304 ステンレスパイプに, 幅 $12 \mathrm{~mm}$, 厚さ $3 \mathrm{~mm}$ の OCC ステライト板状鋳塊(ステライトNo. 12) に研削加工を施し， それを小径のステンレス溶接棒を用いてTIG 溶接したもので ある、な就，この製品は，取り付仔る装置により刃の高さ，角 度などが僅かながら異なっていたため，その製品ごとに鋳型を 作製するよりも、ニアネットシェイプの錆塊から成形する方が コスト的にも有利であり，このように板状鋳塊を用いた．従来 から，ステライトを用いたカッタ一類への肉盛溶接は盛んに行 われている。しかしその場合，刃先のみを施すことが任とんど であり，このように为全体をスデイトで作製することは，製 品の歪名の発生や作業性を考点て行われていなかった，OCC 鋳塊を用いることにより刃全体をステライトで作製でき，その ことにより刃先が摩耗してる研磨することにより再使用が可能 となった。

Fig. 9 K示したスキッドレールは, 熱間鍛造を行ら前の誘導 加熱㶥へのビレットの搬送に用いられる. 従来からステライト の肉盛溶接により作製されていた。このレール上を搬送される ビレットの表面温度は，1000 $1250^{\circ} \mathrm{C}$ 加熱されることから，
管状の母材内には冷却水を流して使用されている．写真の製品 は, SUS316L ステンレスパイプに, 幅 $6 \mathrm{~mm}$, 厚さ $3 \mathrm{~mm} の$ OCC スライト四角棒状鋳塊(ステライトNo.1)を，溶接棒 を用いずに TIG 溶接のアーク熱により母材とOCC 鋳塊の合 わせ面を溶融し接合させたものである．現在，この肉盛部をせ ラミックスに代える研究る行われているが，破損した場合，ビ レットに傷が付きやすいことや，破損や摩耗の修復を行らこと が困難であるといら問題がある。これに対し OCC 鋳塊をレー ルKした場合は，修復は肉盛溶接が可能であり，七ラミックス などのよらな問題は生じない，

\section{(2) ろう付けによる接合}

接合すべき材料扰よび母材を溶融することなく接合する力法 としてろら付け法がある。万う付け法(3)は，溶接できないよう な薄肉母材への接合や，精密な接合も容易にでき，しか子製品 の歪を少なく抑光て接合することが可能である。地，溶接作 業は，熟練を必要とするが，ろら付け作業は，あまり訓練を要 さない.

Fig. 10 火，一辺が $10 \mathrm{~mm}$ の OCC ステライト三角棒状鋳塊 を, SUS316L ステンレス鋼に、ニッケルろう(B Ni-2)を用い て接合した例を示寸。このよらなろら付けは，同時に多数の製 品の接合が可能であり，小部品を大量に製造するのに適してい ると考觉られる。

\section{(3) かしめ接合}

溶接などでの接合が不可能な, しか子融点や熱膨張率の全く 異なる材料との接合方法として，母材の締め付けによるかしめ 接合がある、これは，単純な機械的な接合で市るため自動化む 非常に容易であると考えられる。

Fig. 11 K，幅 $12 \mathrm{~mm}$, 厚さ $6 \mathrm{~mm}$ の OCC ステライト四角 棒状鋳塊を，アルミニウム合金に接合した例を示した。な拉， 接合性をより高めるために OCC 四角棒状鋳塊を研削加工に上 り台形に成形したものを用いた，従来，融点が低いアルミニウ ム合金などに対するステライトを用いた製品は作製されていな かったが，このように棒材のかしめ接合を用いれば，ステライ トを用いた部分強化が可能となる。



Fig. 10 OCC triangular rod joined by brazing as an alternative method to the weld deposit technique. 


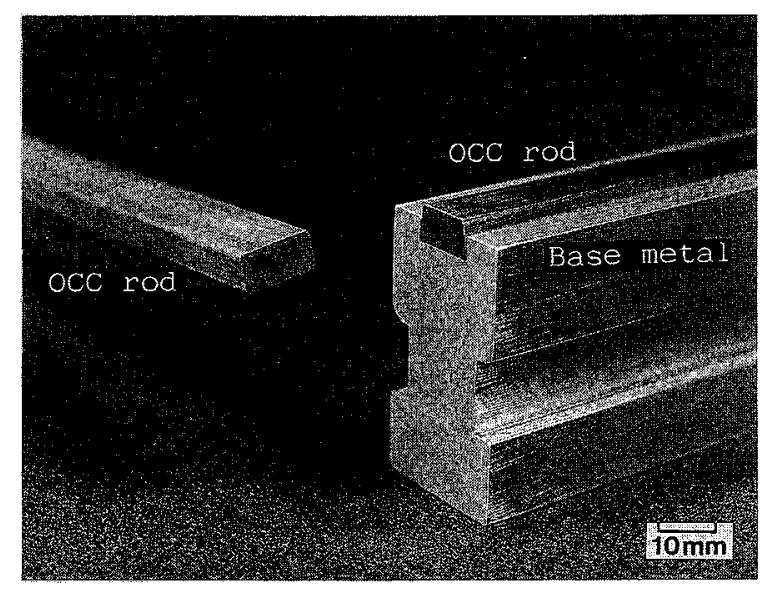

Fig. 11 OCC rectangular rod used for inlaying.

\section{N. 結言}

OCCプロセスで得られたステライト鋳塊と従来から行われ
ているステライトの肉盛溶接による肉盛部との耐食珄，耐摩耗 性，酎衝撃性について比較した結果，以下のことが明らか沉な った.

（1） OCC 鋳塊は肉盛金属に比へ，耐食性が優れている.

（2） OCC 鋳塊の長さ方向に相手材を摺動させることにより， 耐摩耗性は肉盛金属より向上する。

（3）OCC 鈜塊の長さ方向炕垂直に衝撃が加わった場合，ス テライトの欠点とされている䝰衝撃性が高くなる.

（4） OCC 鋳塊を母材に接合する方法として，溶接，万う付 け叔よびかしめ接合などが可能であり，これらを使用形状，用 途に合わせて適切に用いれば，肉盛溶接上り簡単にしかる従来 の製造法で汢困難もしくは不可能と考えられていた製品も得ら れる。

\section{文献}

（1）大野篤美: 特許 1049146 号.

（2）山崎裕之, 大野篤美, 清水亭: 日本金属学会誌, 58(1994), 37.

（3）恩澤忠男：溶接技術(産報出版)，7(1992)，64. 